\title{
Environmental Factors and Beta2-Adrenergic Receptor Polymorphism: Influence on the Energy Expenditure and Nutritional Status of Obese Women
}

\author{
Eliane Lopes Rosado ${ }^{1} \cdot$ Josefina Bressan $^{2} \cdot J$. Alfredo Martínez ${ }^{3}$
}

Received: 28 August 2014 / Accepted: 23 February 2015 / Published online: 18 April 2015

(C) AOCS 2015

\begin{abstract}
Our aim was to evaluate the influence of the Gln27Glu polymorphism of the $\beta_{2}$-adrenergic receptor $\left(\operatorname{ADR} \beta_{2}\right)$ gene, fat intake and physical activity on the energy expenditure (EE) and nutritional status of obese women. Sixty obese women (30-46 years) participated in the study and were assigned to three groups depending on the genotypes: Gln27Gln, Gln27Glu and Glu27Glu. At baseline and after nutritional intervention, the anthropometric and body composition (bioelectrical impedance), dietary, EE (indirect calorimetry) and biochemical variables were measured. All women received a high-fat test meal to determine the postprandial EE (short-term) and an energyrestricted diet for 10 weeks (long term). The frequencies of Gln27Gln, Gln27Glu and Glu27Glu were 36.67, 40.0 and $23.33 \%$, respectively. Anthropometric and biochemical variables and $\mathrm{EE}$ did not differ between groups, although women who had no polymorphism demonstrated decreased carbohydrate oxidation. On the other hand, the Glu27Glu genotype showed a positive relation with EE in physical activity and fat oxidation. The environmental factors and Gln27Glu polymorphism did not influence the nutritional status and EE of obese women, but physical activity in obese women with the polymorphism in the $\mathrm{ADR} \beta_{2}$ gene
\end{abstract}

Eliane Lopes Rosado

elianerosado@nutricao.ufrj.br; elianenut@yahoo.com.br

1 Departamento de Nutrição e Dietética, Instituto de Nutrição Josué de Castro, Universidade Federal do Rio de Janeiro, Avenida Carlos Chagas Filho S/N-CCS-Bloco $\mathrm{J}-2^{\circ}$ andar-Cidade Universitária-Ilha do Fundão, CEP: 21941-590 Rio de Janeiro, RJ, Brazil

2 Departamento de Nutrição e Saúde, Universidade Federal de Viçosa, Viçosa, Brazil

3 Nutrition, Food Science, Physiology and Toxicology, University of Navarra (UNAV), Pamplona, Spain can promote fat oxidation. The results suggest that encouraging the practice of physical exercise is important considering the high frequency of this polymorphism in obese subjects.

Keywords Obesity $\cdot \mathrm{ADR} \beta_{2}$ gene $\cdot$ Fat intake $\cdot$ Physical activity $\cdot$ Energy expenditure $\cdot$ Nutritional status

$\begin{array}{ll}\text { Abbreviations } & \\ \text { ADR } \beta_{2} & \beta_{2} \text { Adrenergic receptor } \\ \text { BEE } & \text { Basal energy expenditure } \\ \text { BCHOX } & \text { Basal carbohydrate oxidation } \\ \text { BFATOX } & \text { Basal fat oxidation } \\ \text { BMI } & \text { Body mass index } \\ \text { Bp } & \text { Base pairs } \\ \text { EE } & \text { Energy expenditure } \\ \text { IRMA } & \text { Immunoradiometric } \\ \text { Mets } & \text { Metabolic equivalent index } \\ \text { MUFA } & \text { Monounsaturated fatty acid } \\ \text { NPBRQ } & \text { Non-protein basal respiratory quotient } \\ \text { NPPPRQ } & \text { Non-protein postprandial respiratory } \\ & \text { quotient } \\ \text { NPRQ } & \text { Non-protein respiratory quotient } \\ \text { PCR } & \text { Polymerase-catalyzed chain reaction } \\ \text { PPEE } & \text { Postprandial energy expenditure } \\ \text { PPCHOX } & \text { Postprandial carbohydrate oxidation } \\ \text { PPFATOX } & \text { Postprandial fat oxidation } \\ \text { PPARgamma2 } & \text { Peroxisome proliferator-activated receptor } \\ \text { PUFA } & \text { gamma 2 } \\ \text { RQ } & \text { Polyunsaturated fatty acids } \\ \text { SD } & \text { Respiratory quotient } \\ \text { SFA } & \text { Standard deviation } \\ \text { S/U } & \text { Saturated fatty acis } \\ \text { TEF } & \text { Relation saturated/unsaturated fatty acid } \\ & \text { Thermogenic effect of food } \\ & \end{array}$




$\begin{array}{ll}\text { TBF } & \text { Total body fat } \\ \text { UNAV } & \text { University of Navarra } \\ \mathrm{VO}_{2} & \text { Oxygen consumption } \\ \mathrm{VCO}_{2} & \text { Carbon dioxide production } \\ \mathrm{WC} & \text { Waist circumference } \\ \text { W/H } & \text { Waist-hip circumference ratio }\end{array}$

\section{Background}

Obesity is a multifactorial disease that is currently considered a global epidemic $[1,2]$. In addition to unhealthy lifestyles, it has been argued that the gene-environment interaction is involved in the onset of obesity; however, assessing genetic influences is complex because they are determined by the interplay of many genes with dietary and physical activity patterns [3, 4].

Efforts to identify candidate genes for obesity have concentrated on adipose tissue, since thermogenesis regulation through the sympathetic nervous system carried out by brown adipose tissue is mediated by the $\beta_{2}$ adrenergic receptor $\left(\mathrm{ADR} \beta_{2}\right)[5]$.

Genes involved in the regulation of catecholamine function may be important in obesity because of the role catecholamines play in energy expenditure (EE) and lipolysis $[6,7] . A D R \beta_{2}$ is a mediator of the lipolytic effects of catecholamines [6] participating in energetic homeostasis because they stimulate the reduction of glycogen use and increase of lipid mobilization [7]. Abdominal fat has a higher density of ADR $\beta 2$; therefore, in obese individuals with a larger waist circumference (WC), ADR $\beta 2$ gene activity levels are higher [6].

Large et al. [8] detected three genetic variations in the ADR $\beta_{2}$ gene, Arg16Glu, Gln27Glu and Thr164Ile. The frequency of obese women who possessed the Glu27 variant was higher (48\%) compared with those of normal weight (30\%). The opposite occurred with the Gln27 allele being more frequent in normal-weight women.

In a meta-analysis, Jalba et al. [9] verified that the presence of the Glu27 allele in the ADR $\beta_{2}$ gene appears to be a significant risk factor for obesity in Asians, Pacific Islanders and American Indians, but not in Europeans. Considering that the $\mathrm{ADR} \beta_{2}$ gene polymorphism can alter lipolytic functions, it may be a candidate for obesity [10]. Large et al. [8] also found a positive association between the Gln27Glu polymorphism and obesity. However, Gjesing et al. [11] evaluated 7808 middle-aged obese white subjects in a case-control study and did not find consistent evidence for an association of this variant with obesity.

Hellström et al. [12] found a positive association between obesity in women and the $\mathrm{ADR} \beta_{2}$ gene polymorphism, but did not in men, suggesting the effect of sex on the frequency of polymorphism. However, González
Sánchez et al. [13] conducted a cross-sectional populationbased study with 666 nonrelated adults, aged 35-64 years, and suggested the Glu 27 allele of $\mathrm{ADR} \beta_{2}$ may be a risk factor in men, but not women, for the accumulation of visceral fat and for its association with the development of type 2 diabetes mellitus.

The influence of the $\mathrm{ADR} \beta_{2}$ gene polymorphism on obesity may depend on environmental factors. Arner [14] verified that an interaction between the $\mathrm{ADR} \beta_{2}$ gene polymorphism and body mass index (BMI) was observed in sedentary individuals, but not in those who performed physical activity. Gungor et al. [15] observed that with physical exercise, the individuals with the Glu allele in the $\operatorname{ADR} \beta_{2}$ gene have a lower maximum volume of oxygen, suggesting a reduction of lipolysis and increase in the respiratory quotient (RQ).

In addition to the genetic factor, Williams [16] suggests that, in Western societies, obesity is greatly influenced by environmental factors, considering that subjects of the same community living in the same environment vary in body size and composition genetically determined as a response to the environment.

Dietary fat differs in fatty acid chain length, the degree of saturation, and the position and stoichiometric doublebound configuration, affecting their oxidation rates. Saturated fatty acids (SFAs) have a slower oxidation speed than polyunsaturated fatty acids (PUFAs); the former favor fat deposition. Monounsaturated fatty acids (MUFAs) favor fat deposition as an energy source in fat tissue compared with PUFA, thus exerting less control on appetite [17].

Rosado et al. [18] verified that obese women with peroxisome proliferator-activated receptor gamma 2 (PPARgamma2) and $\mathrm{ADR} \beta_{2}$ gene polymorphism showed a higher postprandial EE after high-fat and SFA meals compared with obese women with only the PPARgamma2 polymorphism or absence of the polymorphism in both genes. Rosado et al. [19] recommended the control of the fats and SFA intake in obese women with Pro12Pro/Gln27Gln and Pro12Pro/Gln27Glu genotypes, and MUFA in Pro12Pro/ Glu27Glu. In Pro12Ala/Gln27Glu, AGPI intake can result in greater body weight loss. Therefore, there is an interaction between genes.

Martínez et al. [20] verified that genotype-environment interactions may appear when the impact of lifestyle factors (e.g., diet) on a phenotype (e.g., BMI $>30 \mathrm{~kg} / \mathrm{m}^{2}$ ) differs by genotype. A case-control study (obese subjects vs. normal weight controls) was conducted to assess a possible effect modification on the obesity risk of the Gln27Glu polymorphism for the $\mathrm{ADR} \beta_{2}$ gene depending on dietary intake. The obesity incidence was not directly affected by the polymorphism. They found a positive association of carbohydrate intake with insulin among women carrying the Gln27Glu polymorphism. This gene-nutrient 
interaction emphasizes the importance of examining the outcome of some obesity-related mutations depending on lifestyle (including diet) and may explain the heterogeneity of findings from previous studies.

The purpose of this article is to assess the influence of the interactions between the Gln27Glu polymorphism in the $\mathrm{ADR} \beta_{2}$ gene on EE and nutritional status according to dietary fat and physical activity in obese women.

\section{Materials and Methods}

\section{Subjects}

Sixty obese Spanish females $\left(\mathrm{BMI}=37.66 \pm 6.24 \mathrm{~kg} / \mathrm{m}^{2}\right)$ ranging between 20 and 49 years of age (34.59 \pm 7.56$)$ were selected to participate in an interventional trial aiming at comparing both the acute and long-term effects of dietary fat intake on EE, body composition and biochemistry variables depending on the $\mathrm{ADR} \beta_{2}$ gene polymorphism. The study was performed at the Nutrition, Food Sciences and Toxicology Unit of the Clinic of the Navarra University (UNAV), Spain.

Women with a BMI $\geq 30 \mathrm{~kg} / \mathrm{m}^{2}$ and regular menstruation with no chronic diseases were included, and their clinical and biochemical variables were evaluated. The exclusion criteria were as follows: chronic diseases such as diabetes, dyslipidemia, or hypertension; alcoholism or drug dependence; a restrictive diet during the 3 months prior to study; or a recent weight change of $>3 \mathrm{~kg}$ in the previous 3 months. The volunteers were categorized into three experimental groups: Gln27Gln, Gln27Glu and Glu27Glu.

\section{Ethical Approval}

The volunteers were informed about the objectives and methodology of the study before all of them signed an informed consent form, which had been previously approved by the Research Ethics Committee of the UNAV [protocol 24(2)/2004].

\section{Experimental Design}

The experimental design is presented in Fig. 1. The study included short- and long-term nutritional interventions. At baseline, the habitual dietary intake was evaluated using a weighed food record, including 2 weekdays and 1 weekend day [21]. Also the level of physical activity was assessed by a questionnaire using the METs (metabolic equivalent index) [22] considering the frequency and type of activity.

Women came to the metabolic unit after $12 \mathrm{~h}$ of fasting (8:00 a.m.), and their standing height, body weight and body composition were measured. Fasting blood extraction was performed for biochemical and molecular analysis. After resting for $30 \mathrm{~min}$, oxygen consumption $\left(\mathrm{VO}_{2}\right)$ and carbon dioxide production $\left(\mathrm{VCO}_{2}\right)$ were measured over a 30-min period using open-circuit indirect calorimetry in order to calculate the basal energy expenditure (BEE) and non-protein respiratory quotient (NPRQ) with validated equations [18, 23]. A standard test meal (high fat and SFA) was provided and consumed within a $20-\mathrm{min}$ period by every volunteer. After the test meal, the postprandial $\mathrm{VO}_{2}$ and $\mathrm{VCO}_{2}$ were recorded during a 3-h period to estimate the postprandial energy expenditure (PPEE).

To evaluate the dietary effects in the long term, the volunteers were given a hypocaloric diet $(-30 \%$ estimated $\mathrm{EE})$ for 10 weeks and were monitored every 15 days. After this period (70 days), this dietary intervention was evaluated by means of food records as well as anthropometrics, body composition measurements and BEE.

\section{Dietary Intervention}

A standard test meal contained $50 \%$ of the individual's BEE and $90 \%$ SFA. A high-fat and SFA meal had $95 \%$ fat-Fraîche nata (Champion Hendave, France).

A hypocaloric diet was prescribed individually with a $30 \%$ energy restriction (500-1000 kcal) after calculating the resting EE values according to the WHO standards [24] and applying an individualized physical activity factor [25]. The diet comprised a normal distribution of carbohydrates, proteins and fats. Caloric restriction was corroborated with the basal measurement of EE carried out on the intervention day. Dietary compliance was monitored by biweekly dietary recalls.

\section{Laboratory Analysis}

Blood samples were used for insulin, leptin and triglyceride serum levels analyses. Insulin was determined by radioimmunoassay technique [26], while leptin was evaluated by immunoradiometric (IRMA) assay (Diagnostic Systems Laboratories, Inc.) [27]. Triglycerides were evaluated using a colorimetric enzymatic reaction [26].

\section{Anthropometric Analysis}

The women were weighed using a microdigital electronic balance (Seca model 700; lorca Medica, Pamplona, Spain) with $150-\mathrm{kg}$ capacity and $100-\mathrm{g}$ precision. Height was determined using a $0.5-\mathrm{cm}$ scale vertical anthropometer [28]. BMI was calculated and classified according to the WHO standards [29], and the relationship between the WC and hip circumference $(\mathrm{W} / \mathrm{H})$ was determined [30, 31]. The WC was also evaluated independently because of its relation with comorbidity risks [30]. The bioelectrical 
Fig. 1 Experimental design

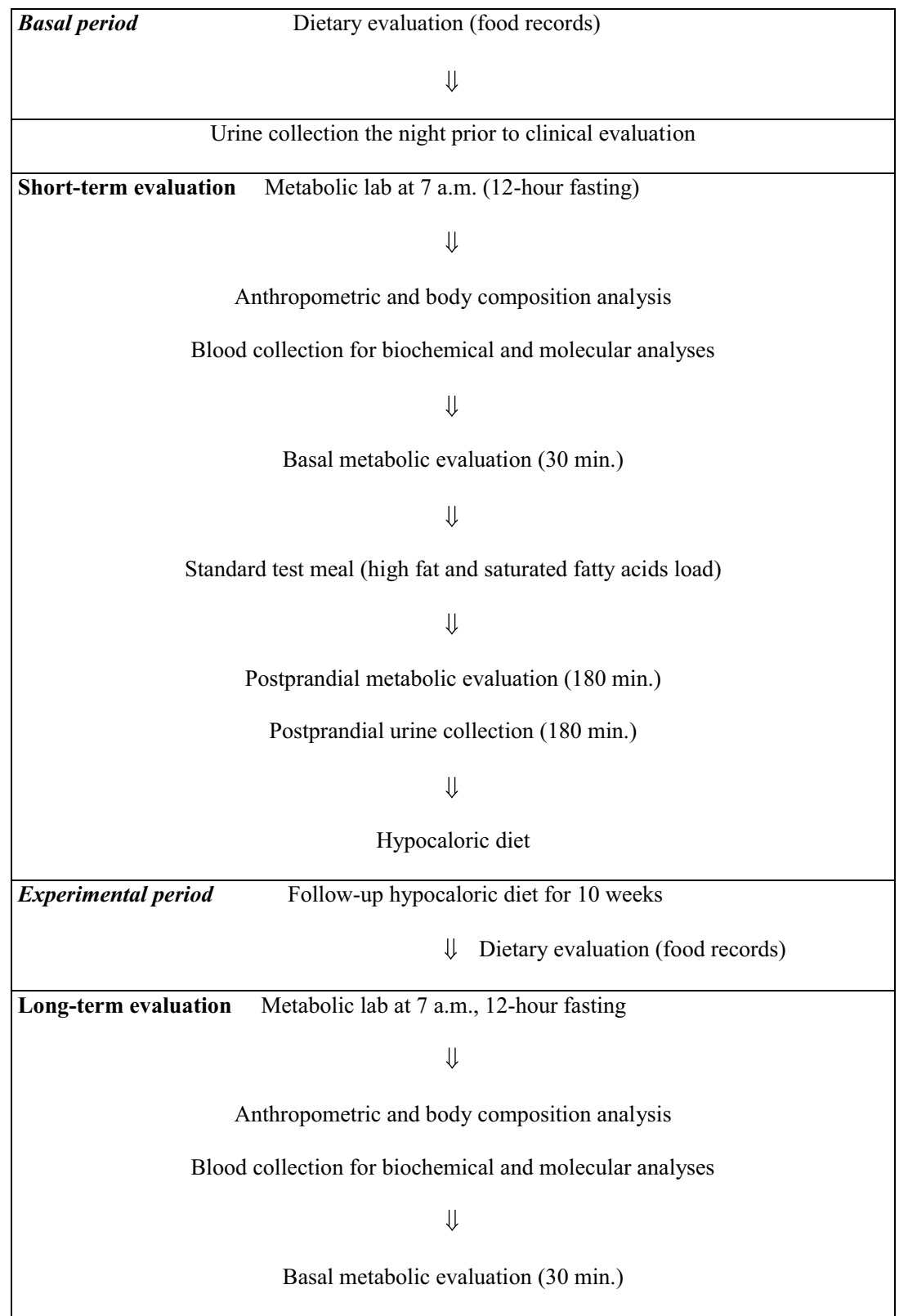

impedance (Biodynamics model 310; Biodynamics Corp., Seattle, WA, USA) method was used to evaluate total body fat $(\mathrm{TBF})$ contents $[26,32]$.

\section{Energy Expenditure Analysis}

The values concerning $\mathrm{VO}_{2}$ and $\mathrm{VCO}_{2}$ were measured at baseline and postprandially by open circuit indirect calorimetry with a canopy system (Deltatrac II, Datex, Finland). Before each test, $\mathrm{O}_{2}$ and $\mathrm{CO}_{2}$ sensors were calibrated using gas mixtures of precisely known $\mathrm{O}_{2}$ and $\mathrm{CO}_{2}$ concentrations. BEE, NPRQ and macronutrient oxidation were calculated using measurements of $\mathrm{O}_{2}$ consumption, $\mathrm{CO}_{2}$ production $(\mathrm{ml} / \mathrm{min})$ and urinary nitrogen excretion [18,
24]. After the test meal intake, the thermogenic effect of food (TEF) was measured during a 180-min period using the same indirect calorimetry system; it was calculated as PPEE and expressed in kilocalories. PPEE was calculated based on postprandial $\mathrm{O}_{2}$ consumption, $\mathrm{CO}_{2}$ production ( $\mathrm{ml} / \mathrm{min})$ and nitrogen excretion. The substrate oxidation rate was calculated based on $\mathrm{VO}_{2}$, nitrogen excretion and NPRQ in the basal (NPBRQ) and postprandial (NPPPRQ) periods to determine basal fat (BFATOX) and carbohydrate oxidation (BCHOX) as well as postprandial fat (PPFATOX) and carbohydrate oxidation (PPCHOX), respectively [23].

The urinary urea values used for assessing EE were obtained from urine collected during 12-h fasting and during the test meal to evaluate fasting and postprandial 
urinary nitrogen, respectively. The urea concentration for urinary nitrogen analyses was determined using the enzymatic method with urease and desydrogenase glutamate, which was automated using COBAS MIRA equipment (Roche, Switzerland).

\section{Molecular Analysis}

Genomic DNA was isolated from white cells in blood samples by organic extraction (phenol/chloroform) based on a density gradient centrifugation [18]. The samples were quantified in a Nanodrop ND-1000 spectrophotometer (Fisher Scientific, Madrid, Spain) at 260, 270, 280 and $310 \mathrm{~nm}$ and kept at $-20^{\circ} \mathrm{C}$ at a concentration of $100 \mathrm{ng} / \mu 1$.

The differentiation of genotypes Gln27Gln, Gln27Glu and Glu27Glu in the $A D R \beta_{2}$ gene was carried out by means of a polymerase-catalyzed chain reaction (PCR) [33], available in the DNA GenBank Y00106 (2003) [34]. The primers used were $5^{\prime}$ CCGCCGTGGGTCCGCC $3^{\prime}$ and $5^{\prime}$ CCATGACCAGATCAGCAGCAC $3^{\prime}$. The cycling conditions were as follows: a curling temperature of $65^{\circ} \mathrm{C}$, a denaturation temperature/time of $94^{\circ} \mathrm{C} / 5 \mathrm{~min}$ and an extension temperature/time of $72{ }^{\circ} \mathrm{C} / 30 \mathrm{~s}$, totaling 35 cycles. The generated fragment was 310 base pairs (bp). After enzymatic digestion of the sample $\left(37^{\circ} \mathrm{C} / 180 \mathrm{~min}\right)$ using the restriction enzyme Ita $\mathrm{I}$, the following fragments were generated: 171, 84 and 55 bp (Gln27Gln); 226, 171, 84 and 55 bp (Gln27Glu); 226 and 84 bp (Glu27Glu).

\section{Statistical Analysis}

Data are presented as means \pm standard deviation (SD). The comparison between groups and analyses of the effects of the intervention in the long term were evaluated by ANOVA and paired tests, respectively, at probabilities of $5 \%$. The Pearson correlation coefficient was used to evaluate the relationship among anthropometrical, dietary and metabolic variables. The Statistical Package for Social Sciences 17.0 software (SPSS; SPSS Inc., Chicago, IL, USA) was used for the statistical analyses.

\section{Results}

The prevalence of genotypes Gln27Gln, Gln27Glu and Glu27Glu was $36.67 \%(n=22), 40.00 \%(n=24)$ and $23.33 \%(n=14)$, respectively.

At baseline, no differences $(p>0.05)$ were found between groups regarding the usual energy intake, fat, carbohydrates, proteins, MUFA and SFA, but all groups had high fat, SFA and MUFA levels. Only the PUFA intake was higher in Gln27Glu compared with Gln27Gln (data not shown). Therefore, the dietary pattern at baseline did

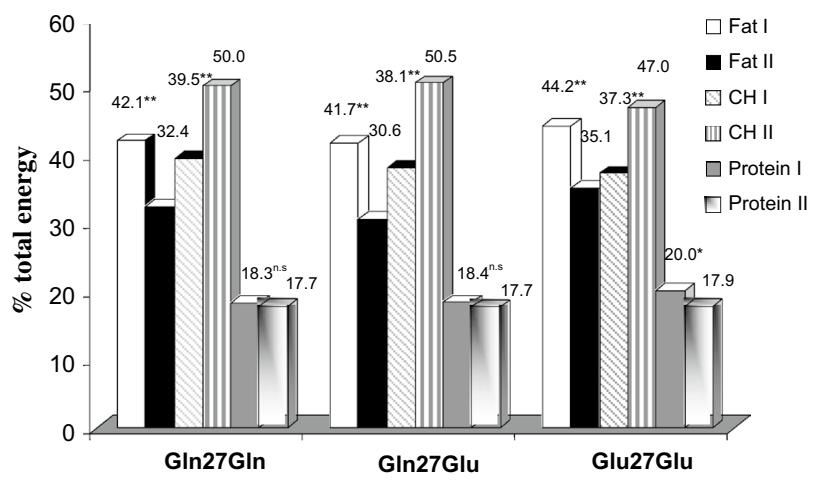

Fig. 2 Differences between the means of the dietary variables (fat, carbohydrate and protein) before (I) and after (II) the intervention in women with Gln27Gln, Gln27Glu and Glu27Glu genotypes in the $\mathrm{ADR} \beta_{2}$ gene. $\mathrm{CH}$ carbohydrate; n.s. not significant; asterisk significant at a $5 \%$ probability; double asterisk significant at a $1 \%$ probability as indicated by paired $t$ test

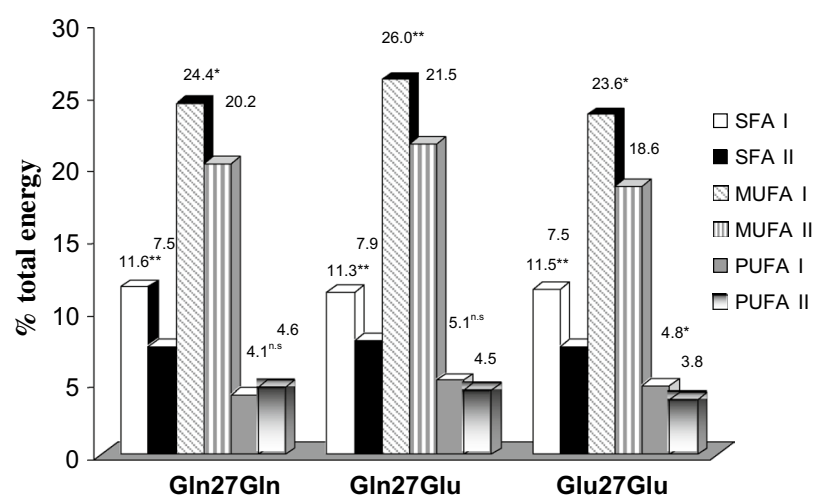

Fig. 3 Differences between the means of the dietary variables (SFA, MUFA and PUFA) before (I) and after (II) intervention in women with Gln27Gln, Gln27Glu and Glu27Glu genotypes in the ADR $\beta_{2}$ gene; n.s. not significant; asterisk significant at a $5 \%$ probability; double asterisk significant at a $1 \%$ probability as indicated by paired $t$ test

not differ between genotypes. After the intervention, there was a reduction in fat, SFA and MUFA intake (Figs. 2, 3), while the carbohydrate intake increased in the three groups (Fig. 2). The energy, carbohydrate, protein, fat, SFA, MUFA and PUFA intake did not differ between groups $(p>0.05)$.

At baseline, age, anthropometrical variables (BMI, W/H, WC, TBF), insulin, leptin, triglycerides and EE did not differ between groups $(p>0.05)$ (Table 1). Also, the PPEE, NPPPRQ, TEF, PPFATOX and PPCHOX did not differ between groups (Table 2).

After dietary intervention, there was no difference in anthropometric variables and $\mathrm{EE}(p>0.05)$ (Table 3$)$. Comparing the baseline and after the intervention by group, there was a reduction in BMI, TBF, WC, W/H and BEE 
Table 1 Descriptive characteristic of the women (mean \pm SD) with the Gln27Gln, Gln27Glu and Glu27Glu genotypes

\begin{tabular}{|c|c|c|c|c|}
\hline & $\operatorname{Gln} 27 \mathrm{Gln}(n=22)$ & Gln27Glu $(n=24)$ & Glu27Glu $(n=14)$ & $p$ value \\
\hline $\operatorname{BMI}\left(\mathrm{kg} / \mathrm{m}^{2}\right)$ & $38.1 \pm 6.7$ & $36.9 \pm 5.5$ & $37.7 \pm 6.6$ & 0.79 \\
\hline $\mathrm{W} / \mathrm{H}$ & $0.82 \pm 0.06$ & $0.84 \pm 0.07$ & $0.86 \pm 0.05$ & 0.21 \\
\hline $\mathrm{WC}(\mathrm{cm})$ & $102.3 \pm 19.5$ & $102.0 \pm 12.8$ & $104.9 \pm 20.6$ & 0.83 \\
\hline $\mathrm{TBF}(\%)$ & $47.1 \pm 5.7$ & $46.5 \pm 4.9$ & $46.7 \pm 5.2$ & 0.94 \\
\hline Insulin $(\mu \mathrm{IU} / \mathrm{ml})$ & $11.1 \pm 7.2$ & $12.4 \pm 9.6$ & $12.1 \pm 5.7$ & 0.85 \\
\hline Leptin (ng/ml) & $82.4 \pm 25.5$ & $73.8 \pm 24.0$ & $76.9 \pm 25.4$ & 0.51 \\
\hline Triglycerides (mg/dl) & $97.1 \pm 43.1$ & $82.4 \pm 31.8$ & $92.0 \pm 33.7$ & 0.41 \\
\hline Weight loss (kg) & $6.8 \pm 3.0$ & $8.1 \pm 2.4$ & $5.7 \pm 4.1$ & 0.07 \\
\hline $\mathrm{BEE}(\mathrm{kcal} / \mathrm{min})$ & $1.20 \pm 0.21$ & $1.20 \pm 0.17$ & $1.21 \pm 0.14$ & 0.94 \\
\hline $\operatorname{BNPRQ}\left(\mathrm{VCO}_{2} / \mathrm{VO}_{2}\right)$ & $0.81 \pm 0.05$ & $0.79 \pm 0.06$ & $0.82 \pm 0.06$ & 0.43 \\
\hline BFATOX (g/min) & $0.07 \pm 0.02$ & $0.07 \pm 0.03$ & $0.06 \pm 0.02$ & 0.49 \\
\hline $\mathrm{BCHOX}(\mathrm{g} / \mathrm{min})$ & $0.08 \pm 0.04$ & $0.08 \pm 0.05$ & $0.10 \pm 0.05$ & 0.46 \\
\hline
\end{tabular}

Values were significantly different at a $5 \%$ probability by ANOVA test

$B M I$ body mass index, $W / H$ waist-hip ratio, $W C$ waist circumference, $T B F$ total body fat, $B E E$ basal energy expenditure, $B N P R Q$ basal nonprotein respiratory quotient, $B F A T O X$ basal fat oxidation, $B C H O X$ basal carbohydrate oxidation

Table 2 Postprandial metabolic variables (mean \pm SD) of Gln27Gln, Gln27Glu and Glu27Glu genotypes after high-fat and saturated fatty acid meals

\begin{tabular}{|c|c|c|c|c|}
\hline Variables/groups & Gln27Gln $(n=22)$ & Gln27Glu $(n=24)$ & Glu27Glu $(n=14)$ & $p$ value \\
\hline PPEE $(\%)$ & $27.6 \pm 2.1$ & $28.5 \pm 2.8$ & $28.4 \pm 2.3$ & 0.49 \\
\hline NPPPRQ $\left(\mathrm{VCO}_{2} / \mathrm{VO}_{2}\right)$ & $0.77 \pm 0.04$ & $0.75 \pm 0.07$ & $0.77 \pm 0.04$ & 0.21 \\
\hline TEF (kcal) & $20.3 \pm 11.6$ & $22.6 \pm 10.5$ & $18.9 \pm 9.8$ & 0.56 \\
\hline PPFATOX (kcal) & $14.6 \pm 4.4$ & $15.7 \pm 5.5$ & $14.1 \pm 4.6$ & 0.57 \\
\hline PPCHOX (kcal) & $12.4 \pm 7.1$ & $9.2 \pm 8.9$ & $12.9 \pm 8.1$ & 0.37 \\
\hline
\end{tabular}

Values were significantly different at a $5 \%$ probability by ANOVA test

$P P E E$ Postprandial energy expenditure, $R Q$ non-protein postprandial respiratory quotient, $T E F$ thermic effect of food, $P P F A T O X$ postprandial fat oxidation, $P$ PCHOX postprandial carbohydrate oxidation

Table 3 Differences between anthropometric and metabolic variables (mean) in baseline and long-term evaluations of Gln27Gln, Gln27Glu and Glu27Glu genotypes

\begin{tabular}{|c|c|c|c|c|c|c|c|c|c|c|}
\hline \multirow[t]{2}{*}{ Variables/groups } & \multicolumn{3}{|c|}{$\operatorname{Gln} 27 \operatorname{Gln}(n=22)$} & \multicolumn{3}{|c|}{ Gln27Glu $(n=24)$} & \multicolumn{3}{|c|}{ Glu27Glu $(n=14)$} & \multirow[t]{2}{*}{$p$ value* } \\
\hline & $\Delta$ & $95 \%$ IC & $p$ value & $\Delta$ & $95 \%$ IC & $p$ value & $\Delta$ & $95 \%$ IC & $p$ value & \\
\hline BMI $\left(\mathrm{kg} \mathrm{m}^{-2}\right)$ & -2.65 & -2.14 to -3.16 & $<0.001$ & -3.17 & -2.76 to -3.58 & $<0.001$ & -2.23 & -1.33 to -3.14 & $<0.001$ & 0.06 \\
\hline $\mathrm{TBF}(\%)$ & -2.58 & -1.92 to -3.24 & $<0.001$ & -3.58 & -2.89 to -4.27 & $<0.001$ & -2.51 & -1.54 to -3.47 & $<0.001$ & 0.06 \\
\hline $\mathrm{WC}(\mathrm{cm})$ & -5.61 & -2.97 to -8.25 & $<0.001$ & -7.71 & -6.03 to -9.39 & $<0.001$ & -5.43 & -2.84 to -8.02 & 0.001 & 0.25 \\
\hline $\mathrm{W} / \mathrm{H}(\mathrm{cm} / \mathrm{cm})$ & -0.01 & -0.002 to -0.03 & 0.03 & -0.02 & -0.003 to -0.03 & 0.02 & -0.03 & -0.02 to -0.05 & $<0.001$ & 0.29 \\
\hline $\operatorname{BEE}\left(\mathrm{kcal} \mathrm{min}^{-1}\right)$ & -0.09 & -0.04 to -0.14 & 0.001 & -0.11 & -0.06 to -0.17 & $<0.001$ & -0.07 & -0.007 to -0.14 & 0.03 & 0.60 \\
\hline $\begin{array}{l}\mathrm{NPRQ}\left(\mathrm{VCO}_{2} /\right. \\
\left.\mathrm{VO}_{2}\right)\end{array}$ & +0.02 & +0.10 to -0.07 & 0.71 & -0.02 & +0.008 to -0.05 & 0.14 & -0.01 & +0.02 to -0.04 & 0.31 & 0.62 \\
\hline BFATOX $\left(\mathrm{g} \mathrm{min}^{-1}\right)$ & +0.001 & +0.01 to -0.01 & 0.88 & +0.001 & +0.009 to -0.009 & 0.97 & +0.001 & +0.01 to -0.007 & 0.49 & 0.96 \\
\hline $\mathrm{BCHOX}\left(\mathrm{g} \mathrm{min}^{-1}\right)$ & -0.021 & -0.0006 to -0.05 & 0.04 & -0.02 & +0.003 to -0.048 & 0.09 & -0.014 & +0.01 to -0.04 & 0.30 & 0.80 \\
\hline
\end{tabular}

$\Delta$ values were significantly different at a $5 \%$ probability by paired test

$B M I$ body mass index, $T B F$ total body fat, $W C$ waist circumference, $W / H$ waist/height ratio, $B E E$ basal energy expenditure, $B N P R Q$ basal non-protein respiratory quotient, $B F A T O X$ basal fat oxidation, $B C H O X$ basal carbohydrate oxidation, $C I$ confidence intervals, $\triangle$ variable differences

* Comparison between groups was performed by ANOVA 
in the three groups. BCHOX decreased only in Gln27Gln (Table 3).

There was no difference among groups in EE with physical activity $(p>0.05)$. Physical activity EE was positively correlated with BMI $(r=0.55, p<0.05)$ and BFATOX in Glu27Glu $(r=0.56, p<0.05)$.

\section{Discussion}

Gene-environment interactions play an important role in obesity, a multifactorial disease [35]. In the future, dietary changes based on the subject's genotype will be an alternative in the prevention and treatment of the disease. Genes involved in the regulation of catecholamine function may be important in the control of obesity [6].

In this study, we did not observe an influence of the Gln27Glu polymorphism on the anthropometric and biochemistry variables and $\mathrm{EE}$. We also did not observe the influence of gene-diet interaction on anthropometric variables and EE, although woman who had no polymorphism demonstrated decreased carbohydrate oxidation. On the other hand, the Glu27Glu genotype showed a relation between $\mathrm{EE}$ and physical activity and fat oxidation.

The frequency of the genotype $\operatorname{ADR} \beta_{2}$ gene was similar to those found in the literature. Meirhaeghe et al. [36] found that the frequency of the $\mathrm{ADR} \beta_{2}$ gene polymorphism is equivalent to three isoforms, with $33.1,51.0$ and $15.9 \%$ for Gln27Gln, Gln27Glu and Glu27Glu, respectively, with similar values in males and females.

Rossum et al. [37] evaluated the frequency of the $\mathrm{ADR} \beta_{2}$ gene polymorphism in different values and BMI in both sexes. Considering obese males, it was found that $30.7,53.0$ and $16.3 \%$ presented genotypes Gln27Gln, Glu$27 \mathrm{Glu}$ and Gln27Glu, respectively, while normal-weight males showed values of 26.7, 55.8 and $17.5 \%$ for the same isoforms. Obese women had a frequency of 34.4, 45.7 and $19.9 \%$ for genotypes Gln27Gln, Gln27Glu and Glu27Glu, respectively. In normal-weight women, the frequency of these genotypes was 31.5, 49.1 and $19.4 \%$. No difference was observed among genotypes between males and females.

Large et al. [8] verified that the frequency of obese women who had the Glu27 variant was higher (48 \%) compared with that of normal-weight women $(30 \%)$. The opposite occurred with the Gln27 allele, which was more frequent in normal-weight women. In our study, the frequency of Glu27 was higher (63.33\%), but was similar to the result in Meirhaeghe et al. [36].

It is important to note that the usual diet of the groups was high fat, low carbohydrate, and high SFA and MUFA. After the intervention, the diets of these groups were adequate in fats, carbohydrates, SFA and MUFA [24, 38].
In this study, anthropometrics, biochemistry and metabolic variables did not differ among groups. According to Hellström et al. [12], the WC did not differ among genotypes. Bouchard et al. [39] reported that gluteal-femoral fat cells have a lower lipolytic response to catecholamines compared with abdominal cells, which have a higher density of beta adrenergic receptors. Due to the presence of the allele variant in $\mathrm{ADR} \beta_{2}$ gene, the lipolytic effect exerted by pancreatic beta cells could be reduced; the density and number of these cells are reduced in the gluteal-femoral region compared with the abdominal. Macho-Azcarate [40] also found no differences between groups in anthropometrics variables and leptin.

Only Glu27Glu showed a positive relationship between EE in physical activity and fat oxidation.

Studies are still controversial regarding the interaction of BMI with physical activity. Arner [14] verified that the interaction between the $A D R \beta_{2}$ gene polymorphism and BMI was observed in sedentary individuals, but not in those who performed physical activity. In this case, the presence of the Glu variant did not alter the effectiveness of exercise. Moreover, Gungor et al. [15] observed that during physical exercise, individuals with the Glu variant in $\operatorname{ADR} \beta_{2}$ have a lower maximum volume of oxygen, suggesting a reduction of lipolysis and increase in RQ.

Macho-Azcarate et al. [40] compared the fat metabolism during exercise between eight obese women with the Glu27Glu genotype and seven obese women with the Gln27Gln genotype, and they found that the fat oxidation was significantly lower the Glu27Glu group during recovery compared to those with Gln27Gln. These data suggest that both lipolysis and fat oxidation promoted by an acute submaximal exercise intervention could be blunted in the polymorphic $\mathrm{ADR} \beta_{2}$ Glu27Glu group of our female obese population.

Moore et al. [41] found that in Glu27Glu the $\mathrm{O}_{2}$ consumption was lower and the increase in body fat was associated with a reduction of the maximal $\mathrm{O}_{2}$ compared with other genotypes, but Meihaeghe et al. [36] verified that physical activity can counteract the effect of genetic predisposition to gain weight and that individuals with $A D R \beta_{2}$ polymorphism can benefit from physical activity to reduce body weight.

However, Saitoh et al. [42] studied polymorphisms of genes associated with obesity, including $\mathrm{ADR} \beta_{2}$, and suggest that obesity and diabetes mellitus are not the result of the presence of an obesity-related gene polymorphism but rather the absence of daily physical activity.

Environmental factors and the $\mathrm{ADR} \beta_{2}$ gene polymorphism did not influence the anthropometrics, biochemistry variables and EE; however, physical activity seems to promote the fat oxidation in obese women with genotype Glu27Glu. We suggest conducting further studies to evaluate 
interactions of environmental factors with several candidate genes; however, it is important to encourage physical exercise considering the high frequency of this polymorphism in obese subjects.

Acknowledgments This work was supported by Coordenação de Aperfeiçoamento de Pessoal de Nível Superior (CAPES).

Conflict of interest The authors declared no competing interests exist.

\section{References}

1. WHO (2013) Statistics of obesity and overweight in the world. www.who.int/mediacentre/factsheets. Accessed in 10 March 2013

2. Stevens GA, Singh GM, Lu Y, Danaei G, Lin JK, Finucane MM, Bahalim AN, McIntire RK, Gutierrez HR, Cowan M, Paciorek CJ, Farzadfar F, Riley L, Ezzati M (2012) National, regional, and global trends in adult overweight and obesity prevalences. Popul Health Metr 20(1):22. doi:10.1186/1478-7954-10-22

3. Phillips CM (2013) Nutrigenetics and metabolic disease: current status and implications for personalized nutrition. Nutrients 5(1):32-57

4. Youngson NA, Morris MJ (2013) What obesity research tells us about epigenetic mechanisms. Philos Trans Soc Lond B Biol Sci 368(1609):20110337. doi:10.1098/rstb.2011.0337

5. Froguel P, Boutin P (2001) Genetics of pathways regulating body weight in the development of obesity in humans. Exp Biol Med 226(11):991-996

6. Meirhaeghe A, Luan J, Selberg-Franks P, Hennings S, Mitchell J, Halsall D, O'Rahilly S, Wareham NJ (2001) The effect of the Gly16Arg polymorphism of the beta(2)-adrenergic receptor gene on plasma free fatty acid levels is modulated by physical activity. J Clin Endocrinol Metab 86(12):5881-5887

7. Jocken JM, Blaak EE, Schiffelers S, Arner P, van Baak MA, Saris WH (2007) Association of a beta-2 adrenoceptor (ADR $\beta 2$ ) gene variant with a blunted in vivo lipolysis and fat oxidation. Int J Obes 31(5):813-819

8. Large V, Hellström L, Reynisdottir S, Lönngvist F, Eriksson P, Lannfelt L, Arner P (1997) Human beta-2 adrenoceptor gene polymorphisms are highly frequent in obesity and associate with altered adipocyte beta-2 adrenoceptor function. J Clin Invest 100(12):3005-3013

9. Jalba MS, Rhoads GG, Demissie K (2008) Association of codon 16 and codon 27 beta2-adrenergic receptor gene polymorphisms with obesity: a meta-analysis. Obesity 16(9):2096-2106

10. Barbe P, Millet L, Galitzky J, Lafontan M, Berlan M (1996) In situ assessment of the role of the beta 1-, beta 2- and beta 3-adrenoceptors in the control of lipolysis and nutritive blood flow in human subcutaneous adipose tissue. Br J Pharmacol 117(5):907-913

11. Gjesing AP, Andersen G, Burgdorf KS, Borch-Johnsen K, Jorgensen T, Hansen T, Pedersen O (2007) Studies of the associations between functional beta2-adrenergic receptor variants and obesity, hypertension and type 2 diabetes in 7,808 white subjects. Diabetology 50(3):563-568

12. Hellström L, Large V, Reynisdottir S, Wahrenberg H, Arner P (1999) The different effects of a Gln27Glu beta 2-adrenoceptor gene polymorphism on obesity in males and in females. J Intern Med 245(3):253-259

13. González Sánches JL, Proenza AM, Martínez Larrad MT, Ramis JM, Fernández Pérez C, Palou A, Serrano Ríos M (2003) The glutamine 27 glutamic acid polymorphism of the beta2-adrenoceptor gene is associated with abdominal obesity and greater risk of impaired glucose tolerance in men but not in women: a population-based study in Spain. Clin Endocrinol 59(4):476-481

14. Arner P (2000) Obesity - a genetic disease of adipose tissue? $\mathrm{Br}$ J Nutr 83(suppl 1):9-16

15. Güngör K, Beydaği H, Bekir N, Arslan C, Süer C, Erbağci I, Ergenoğlu T, Avnacioğlu AS (2002) The impact of acute dynamic exercise on intraocular pressure: role of the beta 2-adrenergic receptor polymorphism. J Int Med Res 30(1):26-33

16. Williams PT (2011) Evidence that obesity risk factor potencies are weight dependent, a phenomenon that may explain accelerated weight gain in western societies. PloS One 6(11):e27657

17. Piers LS, Walker KZ, Stoney RM, Soares MJ, O’Dea K (2002) The influence of the type of dietary fat on postprandial fat oxidation rates: monounsaturated (olive oil) vs saturated fat (cream). Int J Obes 26(6):814-821

18. Rosado EL, Bressan J, Martins MF, Cecon PR, Martínez JA (2007) Polymorphism in the PPARgamma2 and beta2-adrenergic genes and diet lipid effects on body composition, energy expenditure and eating behavior of obese women. Appetite 49(3):635-643

19. Rosado EL, Bressan J, Hernandez JA, Martins MF, Cecon PR (2006) Effect of diet and PPARgamma2 and beta2-adrenergic receptor genes on energy metabolism and body composition in obese women. Nutr Hosp 21(3):317-331

20. Martínez JA, Corbalán MS, Sánches-Villegas A, Forga L, Marti A, Martínez-González MA (2003) Obesity risk is associated with carbohydrate intake in women carrying the Gln27Glu beta2-adrenoceptor polymorphism. J Nutr 133(8):2549-2554

21. Willett W (1998) Nutritional Epidemiology. Oxford University Press, New York, p 514

22. Ainsworth BE, Haskell WL, Whitt MC, Irwin ML, Swartz AM, Strath SJ, O'Brien WL, Bassett DR Jr, Schmitz KH, Emplaincourt PO, Jacobs DR Jr, Leon AS (2000) Compendium of physical activities: an update of activity codes and MET intensities. Med Sci Sports Exerc 32(9 Suppl):498-504

23. Ferrannini E (1988) The theoretical bases of indirect calorimetry: a review. Metabolism 37:287-301

24. WHO (1985) Energy and protein requirements. Report of a joint FAO/WHO/UNU Expert Consulttion. Technical Report Series 724, World Health Organization, Geneva

25. Food and Nutrition Board, National Research Council, National Academy of Sciences (2002) Recommended Dietary Allowances. National Academy Press, Washington, DC

26. Valve R, Sivenius K, Miettinen R, Pihlajamäki J, Deeb SS, Auwerx J, Uusitupa M, Laakso M (1999) Two polymorphisms in the peroxisome proliferator-activated receptor- $\gamma$ gene are associated with severe overweight. J Clin End Metab 84(10):3708-3712

27. Miles LEM, Lipschitz DA, Bieber CP, Cook JD (1974) Measurement of serum ferritin by a 2 -site immunoradiometric assay. Anal Biochem 61:209-224

28. Gibson RS (2005) Principles of nutritional assessment. Oxford, New York, p 908

29. WHO (1998) Obesity: Preventing and managing the global epidemic. Report of a WHO consultation on Obesity, p 276

30. Weinsier RL, Nelson KM, Hensrud DD, Darnell BE, Hunter GR, Schutz Y (1995) Metabolic predictors of obesity. Contribution of resting energy expenditure, thermic effect of food, and fuel utilization to four-year weight gain of post-obese and never-obese women. J Clin Invest 95(3):980-985

31. Després JP, Lemieux I, Prud'homme D (2001) Treatment of obesity: need to focus on high risk abdominally obese patients. BMJ 322:716-720

32. Lukaski HC, Johnson PE, Bolonchuk WW, Lykken GI (1985) Assessment of fat-free mass using bioeletrical impedance measurement of the human body. Am J Clin Nutr 41(4):810-817 
33. Mullis KB, Falooma FA (1987) Specific synthesis of DNA in vitro via a polymerase-catalyzed chain reaction. Methods Enzymol 155:335-350

34. GenBankDNA. Y00106. Human gene for be. [gi:29370]. Approached on 24/01/2003, from http://www.ncbi.nlm.nih.gov/ genbank

35. Marti A, Martínez-González MA, Martínez JA (2008) Interaction between genes and lifestyle factors on obesity. Proc Nutr Soc 67(1):1-8

36. Meirhaeghe A, Helbecque N, Cottel D, Amouyel P (1999) Beta2-adrenoceptor gene polymorphism, body weight, and physical activity. Lancet 13(9156):896

37. van Rossun CT, Hoebee B, Seidell JC, Bouchard C, van Baak MA, de Groot CP, Chagnon M, de Graaf C, Saris WH (2002) Genetic factors as predictors of weight gain in young adult Dutch men and women. Int J Obes 26:517-528

38. World Health Organization/Food and Agricultural Organization (2003) Diet, nutrition and the prevention of chronic disease. WHO Technical Report Series 916, Geneva
39. Bouchard C, Després JP, Mauriege P (1993) Genetic and monogenetic determinants of regional fat distribution. Endocr Rev 141(1):72-93

40. Macho-Azcarate T, Marti A, González A, Martínez JA, Ibañez JM (2002) Gln27Glu polymorphism in the beta2 adrenergic receptor gene and lipid metabolism during exercise in obese women. Int J Obes 26(11):1434-1441

41. Moore GE, Shuldiner AR, Zmuda JM, Ferrell RE, McCole SD, Hagberg JM (2001) Obesity gene variant and elite endurance performance. Metabolism 50(12):1391-1392

42. Saitoh S, Shimoda T, Hamamoto Y, Nakava Y, Nakajima S (2015) Correlations among obesity-associated gene polymorphisms, body composition, and physical activity in patients with type 2 diabetes mellitus. Indian J Endocrinol Metab 19(1):66-71 